ESJ Social Sciences

\title{
Resource-Based Approaches: A Framework for Analyzing Competitiveness in the Context of Reverse Logistics
}

\author{
Asmaa Bentamar \\ (Phd Student in Management Science; Laboratory for Skills Management, \\ Entrepreneurial Innovation and Social Aspects of Organization "GESIAS") \\ Hassan II University/ Faculty of Economic and Social Juridical Sciences, \\ Ain chock,Casablanca, Morocco

\section{Kacem Taj} \\ (Professor of Higher Education; Laboratory for Skills Management, \\ Entrepreneurial Innovation and Social Aspects of Organization "GESIAS") \\ Hassan II University/ Faculty of Economic and Social Juridical Sciences, \\ Ain chock, Casablanca, Morocco \\ Omar Ourahou \\ (Phd Student in Management Science, Prospective Research Laboratory in \\ Finance and Management, National School of Business and Management) \\ Hassan II University/ Faculty of Economic and Social Juridical Sciences, \\ Ain chock, Casablanca, Morocco
}

\section{Doi:10.19044/esj.2021.v17n19p194}

Submitted: 25 April 2021

Accepted: 14 June 2021

Published: 30 June 2021
Copyright 2021 Author(s)

Under Creative Commons BY-NC-ND

4.0 OPEN ACCESS

Cite As:

Bentamar A., Taj K. \& Ourahou O. (2021). Resource-Based Approaches: A Framework for Analyzing Competitiveness in the Context of Reverse Logistics.

European Scientific Journal, ESJ, 17(19), 194. https://doi.org/10.19044/esj.2021.v17n19p194

\section{Abstract}

In a constantly changing society, organizations must adapt and be open to change. Reactivity, variety, costs, deadlines, innovation, increase their competitiveness, increase their flexibility and improve their performance. The approach by resources and capacities is a framework for analyzing competitive advantage. However, the contributions of this approach to the problem of reverse logistics are multiple. The main ambition of this article is therefore to provide a summary of the conceptual contributions. This literature review will allow analysis of the main relationships between resources, capacities and knowledge management and how these approaches can influence the competitiveness of the company, a discussion on the research perspective are 
presented and conceptual models are proposed.

Keywords: Resources, Capacities, Competitiveness, Reverse logistics

\section{Introduction}

The transition to the circular model has changed the form of closedloop supply chain management, combining direct and return logistics flows, the integration of value-creating activities such as reverse logistics into the company's strategic decisions is required due to increased pressure from legislation, consumers, economic and environmental factors, including:

1. Legislation: puts pressure on companies to process the return of their products. As a result, industries such as electronics and the automotive industry are subject to particular legal pressure Bloemhof-Ruwaard et al (2004). These reasons lead companies to participate "voluntarily" in restrictive clauses, either to face the legislation, or to prepare for it De Brito (2004).

2. The emergence of E-commerce and returns policies, as well as consumer rights, all of these factors have created returns Hazen et al (2012).

3. For economic reasons, reverse logistics appears to be an increasingly important strategic advantage for many Tibben-Lembke (2002) companies. The reverse logistics impacts the results of the industrialists who achieve a return rate varying between 5\% and $20 \%$ Daugherty et al (2001) going up to 50\% Prahinski and Kocabasoglu (2006).

Lack of integrated supply chain management strategy influences competitiveness Ramirez (2012), Several authors agreed that effective management of reverse logistics activities allows companies to reduce their costs and increase customer satisfaction and improve image Dowlatshahi (2000), Weeks et al (2010), Chen (2010).

The study of the concept of competitiveness is a major element in research instrategic management.This concept is still complex and enigmatic since the literature review on this subject is very rich.Two main streams presented an analysis of competitiveness; the first is that of Porter, it refers to an industry, that is to say a group of companies directly competing in a market. The second stream is the resource-based approach which considers that the competitiveness of the enterprise is to be sought in the mastery and management of the resources, capacities, skills and knowledge of the enterprise.

The perspective of this paper is to analyze the resource-based theory of the main relationships between resources, capabilities and knowledge 
management and how these approaches can influence the competitiveness of the company.

\section{Literature review:}

\subsection{Methodology:}

This analysis consists of collecting, reading, analyzing, and synthesizing a scientific paper from 1984 to 2018, using keywords related to our research. The papers were extracted from major peer-reviewed international journals and selected using a methodological process that combined electronic search and manual analysis. An electronic tool by "Google Scholar; database; specialized and generalist journals as well as handbooks and theses" were used to identify articles and papers associated with keywords related to the issue. Then, a detailed analysis of the references cited in the articles was carried out, to highlight the main advances in terms of theoretical scoping of the research objects (Dumez, 2011).The objective is to analyze how the resource-based theory supports the competitive advantage of the company in the context of reverse logistics and that companies should seek, analyze and value the sustainable competitive advantages of their resources and capabilities. We also define concepts such as knowledge creation and collaboration, all of which are related to the analysis of competitiveness at the firm level. The objective of the analysis of the literature review is to propose a theoretical conceptual framework which will later be used for future empirical studies.

\subsection{Resource-Based Approaches: A Framework for Competitiveness Analysis}

Resource-based theory is considered one of the most widely used theories in the field of strategic management Métais (2004), Foss and Ishikawa (2007). It argues that a company's resources can be a potential source of competitive advantage Barney (1991) leading to differentiated performance results Aaker (1989), Day and Wensley (1988). However, the deployment, development, operation and combination of these corporate resources and skills must be organized and managed to best achieve better outcomes Teece, Pisano and Shuen (1997)More specifically, companies that are able to properly tailor resources to specific programs or sustainable opportunities are more likely to develop capabilities that result in better performance.

In order to better clarify the concept of resources and given the existence of multiple definitions of resources, several authors have proposed typologies of resources. Our choice is based on the typology developed by Métais (2004) according to the table below. 
Table 1: General Classification of Resources

\begin{tabular}{|l|l|l|}
\hline \multirow{2}{*}{ Ressources tangibles } & \multicolumn{2}{c|}{ Ressources intagibes } \\
\cline { 2 - 3 } & \multicolumn{1}{|c|}{ Organisationnelles } & \multicolumn{1}{c|}{ Marginales } \\
\hline Installations, machines & Savoir faire & Client \\
Ressources humaines & Technologie & Image de l'entreprise \\
Capital financier & Managérial & Relation avec les fournisseurs \\
Brevets,licences, contrats & Gestion de la connaissance & collaboration \\
& Systèmes d'information process & \\
\hline
\end{tabular}

Source:Metais $(2004$, p.37)

Differentiation in the allocation of strategic corporate resources is positively linked to the provision of competitive products and services, leading to basic skills and competitive advantages, the identification of these resources is a major challenge for the company.

The effective allocation and management of resources is seen as a key factor influencing the performance of the company. Peteraf (1993) proposed an analytical framework that identifies four conditions necessary to achieve a competitive advantage: The first condition deals with heterogeneity: for Petraf companies do not have the same resource endowment to ensure the development of their activities. They can therefore value higher production factors or choose an appropriate positioning. The second essential condition for the creation of competitive advantage according to Petraf is « ex post competitive limits »: companies cannot reproduce the winning strategy or limit its benefits because of insulating market mechanisms. The third pillar is the imperfect mobility of the company's assets, resources and skills. That is, the specific factors of the company may not be available on the market to be the subject of the transaction, the last proposal concerns "ex-ante limits": The implementation of a competitive advantage strategy cannot be known a priori as shown in Figure 1.

Amit and Schoemaker (1993) divided the company's "resources" into resources and capabilities. In this respect, the resources are not specific to the enterprise while the capacities are specific to the enterprise, Capabilities refer to a company's ability to organize and deploy its resources to provide a competitive advantage Hall (1993), Chandler and Hanks, (1994).

Resource-based theory supports the idea that holding a stock of resources and skills provides a competitive advantage, whereas while these resources are at the same time marketable, scarce, inimitable and not substitutable, they can create a sustainable competitive advantage in the long term. Nevertheless, some researchers have raised the limits of resource-based theory and highlighted the need for companies to rapidly renew their resources and skills to cope with changes in their environment. 
Figure 1: Competitive advantage foundations from Peteraf (1993, p. 186)

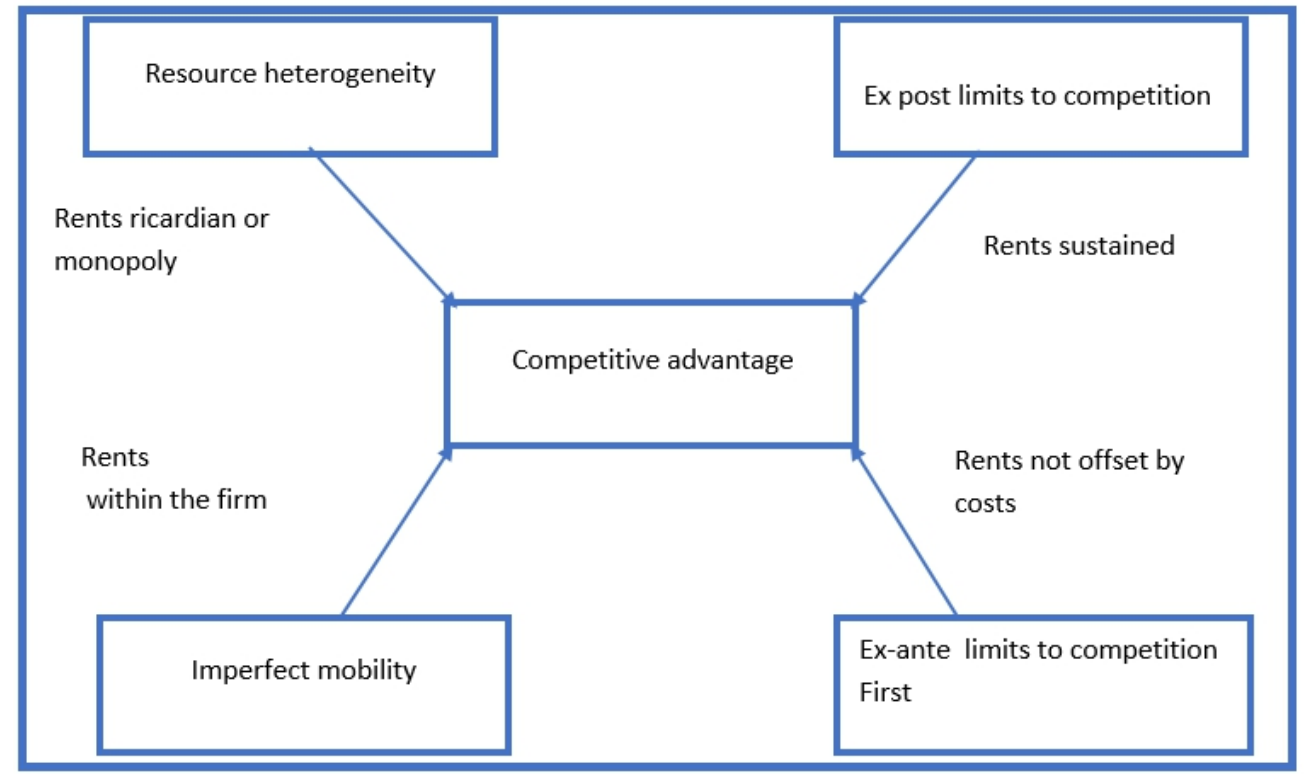

The enduring competitive advantage of a company is grasped with the help of unique resources that are inimitable, valuable, rare, non-substitutable and specific Barney (1991).

Reverse logistics is part of the company's business strategy to achieve a sustainable competitive advantage Jayaraman and luo (2007). This point of view refers to the theory based on resources, the capacity of reverse logistics leads us towards a convergence between economic, ecological and societal gains. All of which contribute to a sustainable competitive advantage for Minner and Kiesmuller (2012), Dias, Junior and Martinez (2016). Reverse logistics is a process that aims to use resources and develop capabilities to derive profitability from Dowlatshahi (2008), as it opens secondary markets for returned products. Rogers and Lembke (2010). These products returned after being upgraded are as necessary resources as raw materials, because the parts and materials of the used products are always of economic value and can be reused. Reverse logistics is also a strategic advantage for Dowlatshahi (2012); Hsu, Tan and Zailani (2016), it translates into the protection of engineering and business technology as an example and according to Dijkhuizen (1997), IBM is committed to recovering its products to maintain and protect its know-how vis-à-vis competitors.

The company's ability to integrate into programs such as reverse logistics Barbosa-Póvoa (2014), Hsu, Tan and Zailani (2016) can be seen as an environmental commitment on its part. The concept is to recover and extract value.For this purpose, reverse logistics is an innovative approach of management Fulconis et al (2009). Innovation enables the company to 
evaluate its own wealth of resources and skills in order to offer more innovative and differentiated products and services. The resource-based approach developed by authors such as Wernerfelt,et al (1984) focuses on the specific resources that enable the company to distinguish itself. In this approach, the roots of competitive advantage are indeed to be sought within the organization.

The ability of companies to offer "green" products can help companies retain their customers and improve the company's image, an asset that can be achieved through the application of the reverse logistics process Tan and Zailani (2016).In addition, the implementation of return policies allows the company to develop its own specific capabilities in the supply and demand market. The returned products can provide detailed information on product efficiency and performance, consumer expectations and profitability of each Jayaraman and luo (2007) product line.Taking into account the return flows in the Logistics function increases the company's competitive capacities and resources on which it must develop the potentials leading to a lasting competitive advantage.

From the resource-based theory it can be argued that reverse logistics is the ability of the company to gain a sustainable competitive advantage Huo et al (2016).

Despite recent advances in logistics and reverse logistics, the need to theoretically develop the strategic role of the logistics function and reverse logistics continues to be a priority Mentzer and Kahn (1995), Stock, (1996), Srivastava and Srivastava (2006). The current competitive environment requires the company to be more agile in the marketplace to succeed. And with the evolution of the economy, which has made it more intensive in information and because knowledge management is a crucial element and a capacity to develop to manage reverse logistics, it was necessary to analyze the relationship between these fields, in order to define the theoretical foundations common to the two fields.

The orientation towards knowledge management has acquired great importance in the enterprise; it is an integral part of resource-based theory and focuses its study on the creation of knowledge as an important resource Grant (1991). Resource-based theory is fully linked to the concepts associated with knowledge creation, showing that knowledge is a strategic asset for the organization Grant (1996), Hunt (1995), Hunt and Morgan (1996), Teece (1998).

\subsection{The creation of knowledge in the context of reverse logistics:}

Knowledge is an intangible asset that creates a source of competitive advantage for Nonaka and Takeuchi (1995). Companies have different technological knowledge and different ways of organizing and developing that 
knowledge, which determines how resources are used to create different products and services. In addition, the company develops its knowledge to benefit from good and bad experiences of the past and keeps good management rules, standard operating procedures to use in the face of changes in its environment Cyert and March (1992).

Knowledge is specific to the company and difficult to transfer to another company. Other companies may not have the same resources or processes to leverage this knowledge. Thus, the knowledge it derives from its experience can be used as a competitive asset. Regarding the information in the management of the return process, it must be taken into account that planning and control are a fairly complex process in reverse logistics, due to the uncertainty in time, the uncertainty of the place of origin and the condition and quality of the returns, in reverse logistics, the information flows converge with the product flows, but have an offset from physical flows, information is generated by another process.

The information can be used to obtain feedback details before the physical flow reaches the Wadhwa and Madaan (2007) process. According to Kokkinaki et al (2001), information and communication technologies (ICT) can be used to minimize uncertainty in the incoming volume of returns. To achieve this, reverse logistics must share information on product design, disassembly and life cycle in real time. Thus, all stakeholders of the reverse logistics system can manage the knowledge and activities related to the return to different levels.Knowledge management can play an important role in the implementation of collection and recovery planning processes when there is a high degree of uncertainty. In addition, the recovery phase is an essential step of the reverse logistics process concerning the quality, knowledge and information about the returned product, which is another unknown factor.

Knowledge management in reverse logistics integrates information from external and internal elements of the reverse logistics process, helps the partners of the reverse logistics system to make the appropriate choices, supports the process and manages the Wadhwa and Madaan collaborations (2007). In order to use knowledge as a point of differentiation from competitors and to benefit from it, The degree of importance of the knowledge generated in the different points of the reverse logistics process should be determined as presented in Table 2. 
Table 2: Knowledge Management Dimension in Reverse Logistics from Wadhwa and

\begin{tabular}{|l|l|l|}
\hline $\begin{array}{l}\text { Source of } \\
\text { Knowledge }\end{array}$ & Type of knowledge. & Knowledge application \\
\hline Collection phase & $\begin{array}{l}\text { Availability of the collection } \\
\text { centre } \\
\text { Transport distance } \\
\text { Transport time } \\
\text { Cost of transport } \\
\text { Classification of products }\end{array}$ & $\begin{array}{l}\text { SeparationSpecialist } \\
\text { Inspection }\end{array}$ \\
\hline \multirow{5}{*}{ Recovery phase } & $\begin{array}{l}\text { Inventory } \\
\text { Inspection / Separation } \\
\text { Product design knowledge and } \\
\text { technical knowledge } \\
\text { Cost of refurbishment } \\
\text { Time Awareness }\end{array}$ & $\begin{array}{l}\text { Product design and } \\
\text { Pevelopment } \\
\text { Production planning } \\
\text { and collection and } \\
\text { distribution control }\end{array}$ \\
\hline \multirow{3}{*}{ Kistribution } & $\begin{array}{l}\text { Distribution cost and time } \\
\text { Customer feedback and } \\
\text { Knowledge of the availability } \\
\text { of orders }\end{array}$ & $\begin{array}{l}\text { Retailers } \\
\text { The customers } \\
\text { Recovery and } \\
\text { collection phase }\end{array}$ \\
\hline
\end{tabular}

To optimize the reverse logistics system, all elements of reverse logistics must be integrated to streamline knowledge transfer. Connectivity is the first attribute that allows the flow of knowledge. The second attribute is the communication of knowledge in a way that enables all elements to make decisions that maximize customer value while reducing costs and cycle time of product recovery and referral to a new potential user. The third attribute is the ability to collaborate in real time, encourage knowledge sharing and enable supply chain flexibility in response to market changes Wadhwa and Madaan (2007).

Nonaka and Konno (1998) presented a contribution from the Knowledge Management Explanation and its role in value creation (Figure 2). 
Figure 2: Taken from Nonaka y Konno (1998)

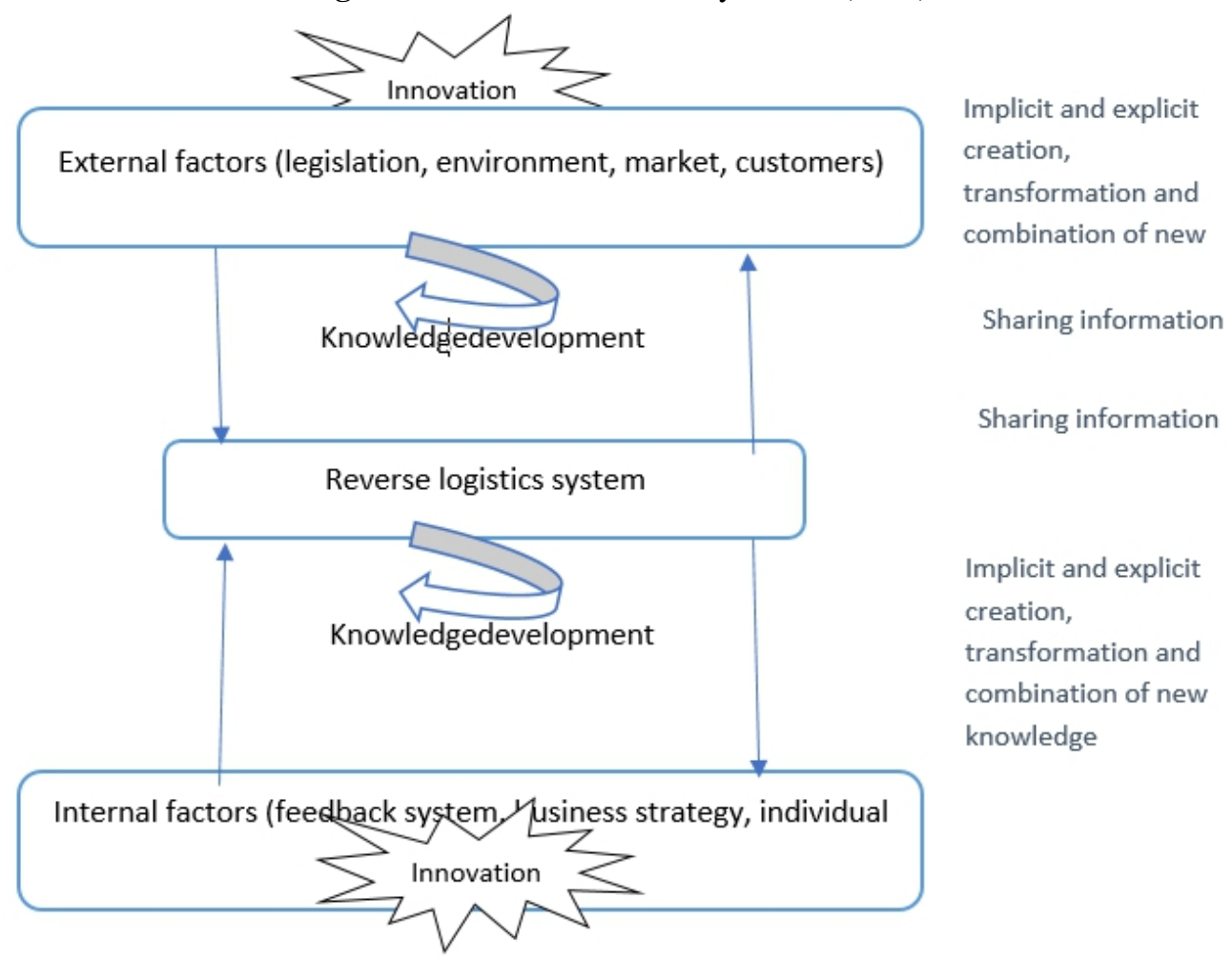

\subsection{Information system and collaboration :}

The increased importance of the role played by information sharing in the management of business relationships justifies the need to develop new capacities to generate, process and share information.

Information and communication systems play an important role in the management and storage of information for future use. Information technology is a competitive advantage for companies that want to optimize their logistics process and ensure profitability. Authors Kaya et al (2014), Olorunniwo and $\mathrm{Li}$ (2010), Daugherty et al (2002) addressed the three dimensions that support information systems in reverse logistics in their research:

- Information system capacity means the accuracy and availability of information;

- Information system compatibility refers to ease of use;

- Information technologies include automated handling equipment, bar codes, EDI and radio frequency.

In addition, one of the problems that organizations face in performing reverse logistics operations is the lack of integrated information systems 
Rogers and Tibben-Lembke (1998). The empirical research by Closs et al. [21] has quantified the relationship between information system capabilities and logistics performance, information support is particularly critical for the efficiency of reverse logistics operations. Moreover, companies recognize the importance of supporting the information system and focus on developing its capacity and compatibility.

Collaboration enables transparent planning of reverse logistics activities; however, defining collaborative framework provides visibility on reverse logistics operations and is aimed at supply chain partners. Organizations that want to manage returned products, engage in a circular economy program. In addition, resource recovery can be achieved through a framework of collaboration. Information systems are a tool for good collaboration between different parts of the logistics system. The theoretical aspect adopted based on resource-based theory supports reverse logistics operations. In addition, collaboration is an integral part of logistics process management based on dynamic optimization work of reverse logistics activities. The collaboration will allow managers to effectively plan their product returns by providing different levels of visibility in their reverse operations planning. Information sharing, strategies, work tools, systems and supply chain processes have an impact on collaborative practices.

According to Dowlatshahi (2005), Autry (2005), the reverse logistics strategy is of crucial importance in managing the reverse transactions from the consumer to the manufacturer Dowlatshahi (2005); Autry (2005) given that the return rate of products is difficult to predict. The sharing of information and the deployment of information and communication systems provides a framework for defining the return rate, according to Vlachos a reverse logistics strategy is therefore necessary to define the return policies and procedures and integrate them into the operations of the global supply chain. According to Morgan et al (2016), collaboration between companies can improve their ability to manage returns, for a successful framework of collaboration, information systems serve as a support in having an impact on the performance of the company.

\section{Conclusion and research perspective:}

Based on the results of this literature review, the choice of our conceptual model will revolve around the source of the competitive advantage through the resources and capacities of the company.The article provides a systematic approach based on knowledge and information systems to achieve performance-based integration. The article highlights the importance of resources in the context of reverse logistics management. He argues that resources must be allocated to the development of reverse logistics programs. our conceptual model will be structured around the following axes: 
- The identification of sources of competitive advantage: the search for strategic resources and skills;

- The conditions for the sustainability of the competitive advantage;

\section{Our research hypotheses can be read as follows:}

H1: The development of reverse logistics is positively linked to the results of the company

$\mathrm{H} 2$ : The proactivity in developing the reverse logistics process is positively related to information flexibility.

H3: Knowledge management is positively linked to the competitiveness of the company.

H4: Collaboration is positively linked to the performance of the company.

H5: The flexibility of the information system is positively linked to the competitiveness of the company.

Therefore, the research model will allow us to study the source of the competitive advantage through the resources and capacities of the company (Figure 3). This model will be applied through an exploratory study in the case of Moroccan companies.

Figure 3: conceptual models according to the literature review

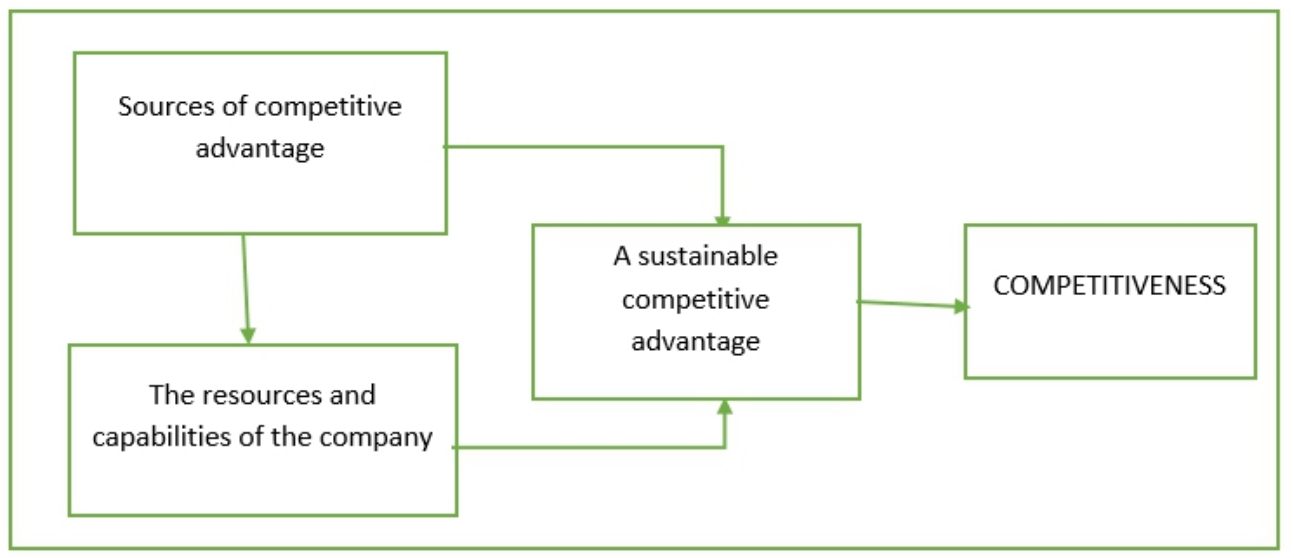

\section{References:}

1. M.Fleischmann and R.Bloemhof, J. M..DEKKER, R.V. D. L. E., V. Nunen, J. A. E. E. et V.Wassenhove, “ Quantitative models for reverse logistics ,a review ", European Journal of Operational Research L. N. 1997, 103(1), 1-17.

2. S.Dowlatshahi, " Developing a Theory of Reverse Logistics". Interfaces. 2000 030. 143-155. 10.1287/inte.30.3.143.11670.

3. A.Gungor and S .M. Gupta, "Issues in environmentally conscious manufacturing and product recovery : a survey Computers \&Industrial Engineering ", 1999, 36:811-853. 
4. R .Carter and Ellram, L. M, "Reverse Logistics : A review of the literature and framework for future investigation," Journal of Business Logistics - Council of Logistics Management 1998 (1), 85-102.

5. D .S Rogers and R,STibben-Lembke, " Going backwards : Reverse logistics trends and practices ". Reverse Logistics Executive Council, Reno, NV, USA, 1998

6. J. R.Stock,"Development and implementation of reverse logistics programs,",Annual Conference Proceeding Council of Logistics Management, Anaheim, CA, USA, 1998, 579-586.

7. V.Daut,"Stratégie de reverse logistics : gestion des process et optimisation,", Logistique \& Management Vol. 13 - N $1,2005$.

8. W.Mtlaa and R.Aggoune "un modèle bi-objectif pour la conception de chaines,", International conference on modelling, optimization and simulation, 2010 .

9. L.Dupont et M.Lauras, "Logistique inverse : un maillon essentiel du développement durable,", Revue française de gestion industrielle, Association française de gestion industrielle, 2007,26 (2), p.5-36. ffhal-01847757.

10. D.Riopel and S.Lambert," Logistique inverse: revue de littérature,", Les Cahiers Du GÉRAD, G-2003-61.

11. S.Mukesh\&F.Andy\&M.Louis,"Building a Sustainable Competitive Advantage". Journal of technology management \& innovation,2013, 8. 47-60. 10.4067/S0718-27242013000200004.

12. C.Brian and M.Jeannette, "A Review of Global Competitiveness Research: Past Advances and Future Directions," Journal of International Marketing,2017,25. 10.1509/jim.16.0053.

13. R.Antonio and G.M.Víctor,'Improving Competitiveness Trough Creation of Knowledge and Reverse Logistics",2011, 22. 443-450. 10.5755/j01.ee.22.4.719.

14. V.Jayaraman and Y.Luo, "Creating Competitive Advantages Through New Value Creation: A Reverse Logistics Perspective," Academy of Management Perspectives,2007,21.

56-73. 10.5465/AMP.2007.25356512.

15. M.E.Porter, "Competitive advantage: Creating and sustaining superior performance", 1985, New York: Free Press.

16. Srivastava, K.Samir , "Network Design for Reverse Logistics",Omega, Vol. 36, No. 4, pp. 535-548, 2008, Available at SSRN

17. S.Chaudhuri and S. Ray, "The competitiveness conundrum: literature review and reflections", Economic and Political Weekly, 1997, p. M83-M91.

18. P.Temple\&P.Swann, (2006). "Competitions and Competitiveness: 
The Case of British Design Awards”, Business Strategy Review,2006.

19. A.Saurabh\&S.Rajesh\&M.Qasim, "A literature review and perspectives in reverse logistics. Resources, Conservation and Recycling,", 97. 10.1016/j.resconrec,2015,02.009.

20. Logistiques vertes 8e Conférence Internationale de modélisation et simulation-MOSIM'10 - 10 au 12 mai 2010 - Hammamet - Tunisie

21. "Evaluation et optimisation des systèmes innovants de production de biens et de services"

22. S.Masson et R.Petiot,"Attractivité Territoriale, Infrastructures Logistiques Et Développement Durable,",Colloque AISRE-ASRDLF 2010.

23. [M. Bennekrouf, L. Benyoucef et Z.Sari, "Problèmes de conception et pilotage des chaînes logistiques inverses et globales : Etat de l'art,", Conférence Internationale de Modélisation et Simulation M.OSIM'10 - 10 au 12 mai 2010 - Hammamet - Tunisie.

24. M.Monnet, "Les stratégies de logistique inversée : Une perspective théorique,", Logistique \& Management- Vol. $19-\mathrm{N}^{\circ} 1,2011$

25. S.Masson et Mr R.Petiot ARSDLF 2012 Belfort 9, 10,11 Juillet 2012

26. L'innovation de services logistiques en contexte de « reverse logistics» «Candidate au Prix Roland Calori »1334.

27. T.Shenawy,"Optimisation Et Conception De Réseau De Logistique Inverse", Université du Québec à Trois-Rivières 2005.

28. A.Landrieu ,'Logistique inverse et collecte des produits techniques en fin de vie .Tournées de véhicules avec contraintes ",Institut National Polytechnique de Grenoble, 2001.

29. M. H .Zerhouni," Intégration des flux inverses dans la gestion des stocks et de la production,", Grenoble Institut National Polytechnique , 2009.

30. T.Boukherroub," Intégration des objectifs du développement durable dans la gestion stratégique et tactique de la chaîne logistique", L'Institut National des Sciences Appliquées de Lyonle, 2013.

31. D.S.Rogers and R.S.Tibben-Lembke,"Going Backwards : reverse logistics trends and practices,",Reverse Logistics Executive Council, Pittsburgh, PA, 1999.

32. M.Fleischmann,"Quantitative Models for Reverse Logistics Promotor(es)" : Prof.dr.ir. J.A.E.E. van Nunen, Prof.dr.ir. R. Dekker Defended : October 5, Lecture Notes in Economics and Mathematical Systems, Volume 501, 2000.

33. D.Aitkadi, D.Riopel, D.Chouinard,et M.Marcotte, "Ingénierie et gestion de la logistique inverse". La Voisier Hermes.Canada,2011

34. M.De Brito,"Managing reverse logistics or reversing logistics management?,2004. 
35. R.Moigne,'L'Economie circulaire : Comment la mettre en oeuvre dans l'entreprise grâce à la Supply Chain revers ?", Dunod.France, 2014.

36. B.Wernerfelt, "A Resource-Based View of the Firm", Strategic Management Journal, 5, 171-180,1984.

37. M.Monnet,"Les stratégies de logistique inversée:une perspective théorique",Logistique et Management 2011.

38. A.R.Seyed,Z.Yu,S.K.Syed, "Reverse Logistics and Challenges: Supply Chain Management of Automobile Industry",SciencePC 2017

39. S.G.Varunkumar "Best practices for reverse logistics management", international ,jornal of advance trencds in enginneering tachnologie.2016.

40. L.Dupont, Ma.Lauras "Logistique inverse : un maillon essentiel dudéveloppement durable",2018

41. A.Jaeglera,T.Bouzdine-Chameevaa,P. Mérieuxa, “Où en est la logistique inverse dans le secteur aéronautique ”,2017. 